\title{
PROMOÇõES CULTURAIS
}

Palestra realizada pelo Prof. Riad Salamuni, Magnífico Reitor da Universidade Federal do Paraná, sobre o tema: "A Estrutura e Ensino da Universidade".

Palestra realizada pelo Prof. Carlos Ribas Santiago, sobre o tema: "A questão da Ordem dos Advogados do Brasil - OAB".

Palestra realizada pelo Prof. Celso Antonio Bandeira de Mello, sobre o tema: "A Estrutura da Faculdade de Direito".

Palestras realizadas pela Profa. Eva Maria Von Münch, da Alemanha Ocidental, sobre os temas: "Homem e Mulher (o desenvolvimento matrimonial e direito do divórcio); "Pais e filhos (a reforma do direito de tutela dos pais)"; "Vida em comum sem certidão de casamento, formas de vida alternativa e seu reconhecimento perante a sociedade e a lei".

Simpósio sobre "Direito e contra-cultura", com a seguinte programação: Prof. Thomas Ziehe, da Cadeira de Ciências da Educação e Psicologia Social da Universidade de Hannover, versando sobre o tema: "O Movimento Alternativo".

Dr. Günter Ellscheid, Presidente do Tribunal Estadual de Justiça de Saarbrücken, sobre o tema: "Decisões Judiciais a respeito de ocupações de moradias".

Prof. Winfried Hassmer, da Cadeíra de Teoria do Direito, Sociologia do Direito e Direito Penal da Universidade Johan Wolfgang Goethe, de Frankfurt, sobre o tema: "Direito, Religião, Sexualidade, problemas de um Direito Penal secularizado".

Conferência proferida pelo Dr. José Francisco Rezek, Ministro do Supremo Tribunal Federal, sobre o tema: "Uma idéia constitucional do Poder Judiciário".

Conferência proferida pelo Dr. Jürgen Samtleben, da Alemanha Ocidental, sobre o tema: "A Constituição da República Federal da Alemanha e a nova Lei de Direito Internacional Privado". 
Aula inaugural do ano letivo de 1988 proferida pelo Prof. Geraldo Ataliba, sobre o tema: "As profissões jurídicas na Constituição de 1988".

Conferência proferida pelo Prof. Dante Romanó, Vice-reitor da UFPr, sobre o tema: "A Universidade Pública Brasileira".

Conferência proferida pelo Prof. Ives Gandra da Silva Martins, sobre o tema: "Constituição e Sistema Tributário".

Conferência proferida pelo Prof. Luiz Alberto Machado, sobre o tema: "A Faculdade de Direito e o Momento Atual".

Palestras proferidas pelo Prof. Dr. Alberto Von Mutius, do Instituto Lorenz, -von-Stein, para Ciências da Adminstração da Universidade Christian-Alberecth, Kiel, Alemanha Ocidental, sobre os temas: "O sistema da formação de juristas na República Federal da Alemanha" e "A proteção ao meio ambiente como finalidade do Estado na Constituição".

Curso de Extensão realizado pelo Departamento de Direito Público, sob a coordenação da Prof. Regina Maria Macedo Nery Ferrari, sobre o tema: "A nova ordem constitucional", quando foram proferidas as seguintes palestras: "A empresa na nova Constituição" - Prof. Marçal Justen Filho; "A Administração Pública na nova ordem constitucional" - Prof. Luiz Bispo; "Princípios Gerais da Constituição" - Prof. Geraldo Ataliba: "O Direito Internacional e a nova ordem constitucional" - Prof. Clèmerson Merlin Clève; "O sistema constitucional tributário" - Prof. Celso Ribeiro Bastos; "O presidencialismo brasileiro" - Prof. Cristian Caubert; "As novas garantias individuais" - Prof. Michel Temmer; "A inconstitucionalidade na Federação" Prof. a Regina Maria Macedo Neri Ferrari; "Princípios constitucionais trabalhistas" Prof.a Ana Maria Toledo Coelho; "A nova feição da propriedade" - Prof. a Maria Garcia; "O Estado e a nova ordem econômica" Prof. Celso Antonio Bandeira Mello. 